$10-1-2013$

\title{
Professional Occupations, Knowledge-Driven Firms, And Entrepreneurship: A National And Regional Analysis
}

\author{
Andrew C. Gross \\ Cleveland State University, a.gross@csuohio.edu \\ Mark Holtzblatt \\ Cleveland State University, m.holtzblatt@csuohio.edu \\ Rajshekar Javalgi \\ Cleveland State University, r.javalgi@csuohio.edu \\ József Poór \\ Szent IstvánUniversity, poojr@t-online.hu
}

Follow this and additional works at: https://engagedscholarship.csuohio.edu/bus_facpub

Part of the Entrepreneurial and Small Business Operations Commons

How does access to this work benefit you? Let us know!

Publisher's Statement

The final publication is available at Springer via http://dx.doi.org/10.1057/be.2013.22

\section{Original Published Citation}

Gross, A.C., Holtzblatt, M., Javalgi, R., Poór, J., \& Solymossy, E. (2013). Professional occupations, knowledge-driven firms, and entrepreneurship; A national and regional analysis. Business Economics, 48(4), 246-259. doi:10.1057/be.2013.22

This Article is brought to you for free and open access by the Monte Ahuja College of Business at EngagedScholarship@CSU. It has been accepted for inclusion in Business Faculty Publications by an authorized administrator of EngagedScholarship@CSU. For more information, please contact library.es@csuohio.edu. 
Professional occupations, knowledge-Driven firms, and entrepreneurship: A national and regional analysis

Andrew C. Gross, Mark Holtzblatt, Rai Javalgi, Jozsef Poor and Solymossy Emeric

The worldwide dominance of Western nations in commercial knowledge-intensive services has declined between 1995 and 2010, but the slippage in revenue was only from 88 to 79 percent. The European Union, and North America remain the two largest regions in consumption and in exporting. Four professional service sectors-accounting, law, engineering, and management consultancy--have shown stability or even growth in the past decade. Entry and expansion requirements in these fields, at home and abroad, constitute barriers for both individual professionals and companies. Entrepreneurship is evident in these sectors, as small and medium size enterprises have nutin-tained their viability against large firms. Only accountancy shows a high degree of concentration, but competition in this sector, too, is expected from the emerging economies, especially China. Professional service firms of the West have forged strong linkages with both domestic and foreign clients via relationship marketing. Technology is an important factor via automation. Although each of the four sectors is facing both external and internal challenges, they continue to grow and appear to be meeting the challenges in part by more innovation and transparency.

Keywords: occupations; prgfessional; knowledge-intensive; services; entrepreneur

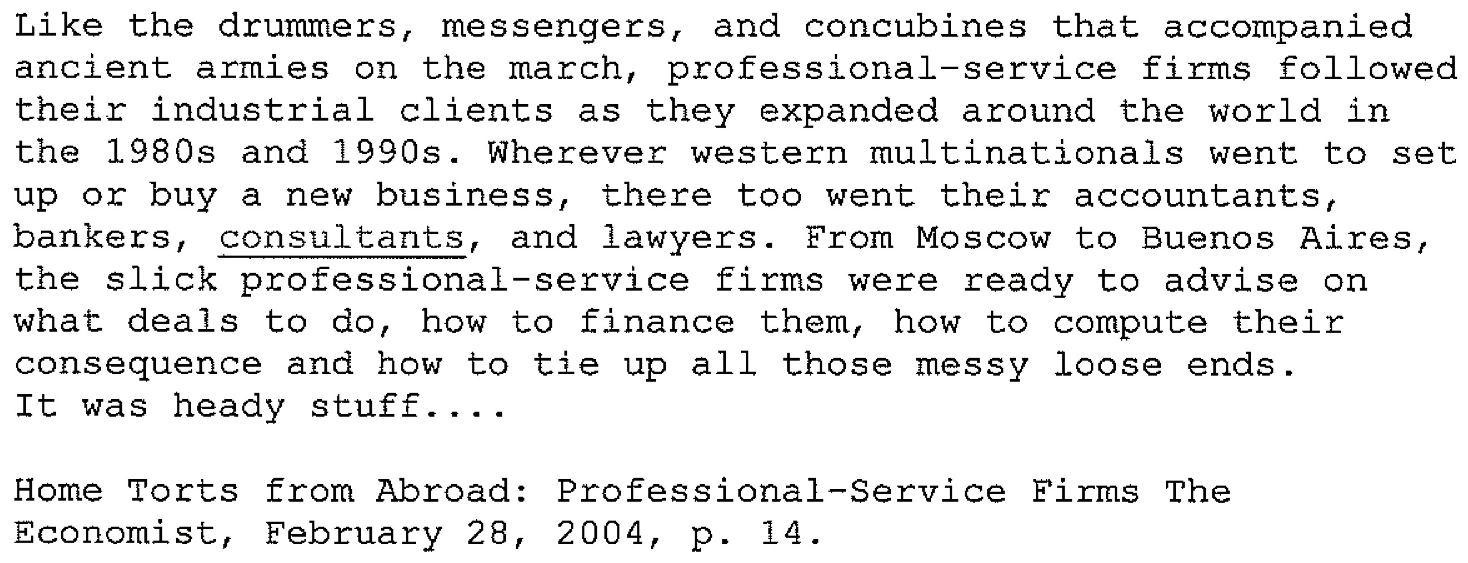

In the 20th century, the tertiary or service sector became dominant in the economies of both developed and developing nations, while the role of the secondary (manufacturing) and the primary (natural resource) sectors declined sharply. In the 21 st century, this trend continues with knowledge-intensive services constituting a significant and growing segment. This field consists of five sub-sectors: business, communication, finance, education, and health services. The first three of these five have been labeled commercial knowledge-intensive services. The absolute size and the growth rates for value added by these services in major industrialized and emerging economies during 1995-2010 are shown in Table 1. The former cluster is far bigger and remains dominant; but the latter is starting to close the gap [Organisation for Economic Cooperation and Development 2001; National Science Board 2012]. 
Table 1. Value Added of Commercial Knowledge-Intensive Services in Selected Major Western and Emerging Nations, $1995--2010$

\begin{tabular}{|c|c|c|c|c|}
\hline \multirow[t]{2}{*}{ Country } & \multicolumn{2}{|c|}{ (Billion } & \multicolumn{2}{|c|}{$\begin{array}{r}\text { Current } \$ \text { and Percent } \\
\text { Annual Growth) }\end{array}$} \\
\hline & 1995 & 2005 & 2010 & $\begin{array}{r}\text { Percent change } \\
110 / \cdot 95\end{array}$ \\
\hline France & 248 & 385 & 522 & $5.1 \%$ \\
\hline Germany & 388 & 482 & 585 & 2.8 \\
\hline Spain & 68 & 141 & 217 & 8.0 \\
\hline United Kingdom & 182 & 473 & 542 & 7.5 \\
\hline United Suites & 1461 & 2972 & 3607 & 6.2 \\
\hline Canada & 79 & 180 & 273 & 8.6 \\
\hline Australia & 69 & 153 & 339 & 11.2 \\
\hline Japan & 767 & 790 & 916 & 1.2 \\
\hline China & 99 & 227 & 714 & 14.1 \\
\hline India & 35 & 88 & 225 & 13.2 \\
\hline Russia & 34 & 92 & 205 & 12.7 \\
\hline Brazil & 96 & 113 & 281 & 7.4 \\
\hline Mexico & 38 & 1.05 & 128 & 8.4 \\
\hline Indonesia & 20 & 26 & 61 & 7.7 \\
\hline Turkey & 23 & 74 & 140 & 12.8 \\
\hline World & 4424 & 7763 & 10901 & 6.2 \\
\hline
\end{tabular}

Source: National Science Board [2012]. Appendix Tables 6-3. NSB cites IHS Global Insight and the World Industry Survey database.

Notes: Definition of commercial knowledge-intensive services per $O E C D$ includes business, financial, and communication services; excludes education and health. Growth rates are computed by authors.

Taking a regional perspective for this 15-year span, we find that the European Union (EU) share of the total value was 29 percent in both 1995 and 2005 , declining only to 26.5 percent in 2010 . The U.S. share rose from 33 percent in 1995 to 38 percent in 2005, but returned to 33 percent in 2010 . Japan declined sharply from 17 percent in 1995 to 10 percent in 2005 and 8 percent in 2010. (These fluctuations in the shares of the EU, the United States, and Japan reflect changes, to a small extent, in the dollar/euro/yen exchange rates). The developing 
countries during this time more than quadrupled output from $\$ 0.5$ trillion to $\$ 2.3$ trillion, going from 12 to 21 percent of the total: but the developed countries also did well by more than doubling their volume from $\$ 3.9$ trillion to $\$ 8.6$ trillion. Thus, while Western nations have lost some of their remarkable dominance in global share, the decline over 15 years was only from 88 to 79 percent.

Commercial knowledge-intensive services have grown at a lively pace in all economies. Contributing to this growth has been international trade, with mutual benefit to both emerging and industrialized nations. Until now, Western nations have been the major exporters. In 2009, the EU was the largest exporter of such services at $\$ 409$ billion and 30 percent of global value, followed by the United States at $\$ 239$ billion and 22 percent. The "Asia-8," including India, was in third place at \$204 billion and 15 percent, with China in fourth place at $\$ 110$ billion and 8 percent. Observers note that the rate of globalization in these service industries is more modest than was the case for high-technology manufacturing [Organisation for Economic Cooperation and Development 2001; National Science Board 2012]. We definitely view this as a positive sign, as it allows for smoother adjustments for the participants across borders and over time.

\section{Professions and Professional Associations}

Knowledge-intensive services are planned and implemented by a professional work force. The original three professional fields are said to be divinity, medicine, and law; later came engineering, architecture, surveying, accounting, and consulting. Professions involve the application of specialized knowledge: a professional occupation is one where the individual's background is characterized by high-level skill, acquired learning, and commitment to both ethical standards and client confidentiality. Continuing education, certification, and membership in a professional body or association is often required to demonstrate ongoing expertise. Growing domestically or internationally is no easy task. In Table 2, we delineate how entry and expansion take place for four key sectors--accounting, legal services, engineering consultancy, and management consultancy.

Table 2. Ease of Entry, Expansion, and Licensure in the United states and Abroad for Small professional Service

Enterprises

\begin{tabular}{lllllll} 
Sector & Entry & \multicolumn{4}{c}{ Expansion } & Licensing \\
& USA & Abroad & USA & Abroad & USA & Abroad \\
$\begin{array}{l}\text { Accounting, } \\
\text { Audit }\end{array}$ & Medium & High & Medium & High & Required & Required \\
$\begin{array}{l}\text { Legal (Law) } \\
\text { services }\end{array}$ & Medium & High & High & High & Required & Required \\
$\begin{array}{l}\text { Engineering } \\
\text { consultancy }\end{array}$ & Medium & High & Medium High & $\begin{array}{l}\text { If work on } \\
\text { infrastructure }\end{array}$ & Will vary \\
$\begin{array}{l}\text { Management } \\
\text { consultancy }\end{array}$ & Low & Medium & Medium High & $\begin{array}{l}\text { Not req'd but } \\
\text { recomm'd }\end{array}$ & $\begin{array}{l}\text { Not req'd; } \\
\text { will vary }\end{array}$
\end{tabular}

Sources: (I) Gross and Poor [2008]. Gross [2012], Poor and Gross [2003], and primary interviews by the authors with select engineering and management consultancics. professional associations, and multinational and national statistical bureaus in Australia. Canada, the European Union, and the United States in 2008-2013.

Professionals are generally held in high esteem; they can form their own firms or be hired by business, government, and nonprofit organizations. Regardless of their post, they tend to assert their status and autonomy to achieve power, capitalize on their expertise by charging high fees, and cluster in associations from which they 
exclude those they deem not qualified. An 85-year-old, oft-cited quote, attributed to G. B. Shaw, states: "All professions are conspiracies against the laity." Indeed, the histories and the characteristics of various professions are colorful and controversial; and their evolution, along with their respective associations, can be traced back several centuries [Carr-Saunders and Wilson 1933; Parsons 1939; Wilensky 1964; Maister 1993; Dezalay and Sugarman 1995; Morgan 1998; Brock, Powell, and Hinings 1999; Baker and Dunn 20031

Professionals stress technical expertise, codes of conduct, and confidentiality for clients; yet government bodies and associations often insert themselves in each sector by requiring demonstration of qualification (or to limit supply). Such certification or licensure can be demanding: for example, to qualify as a professional engineer, the State of Ohio in the United States requires (1) an engineering degree from an accredited university, (2) four years of practice, (3) thorough examinations, and (4) continuing education. As a partial offset to the power of expert individuals and their associations, regulators can opt for certification or licensure, with professionals accepting this as a sign of accreditation to their skills. In some nations, public authorities yield the licensing or certifying process to professional associations. For example, according to Wikipedia, there are now "ten accountancy bodies in the United Kingdom, all of which have been given a Royal Charter although not necessarily considered to hold equivalent-level classifications."

Illustrating further the diversity and the requirements in the case of one set of professional services, Table 3 shows the certification steps required by two management consultancy groups. Clearly, it is no small task to seek either licensure or certification in professional fields. But a key question raised frequently is where professionalism should reside--with the individual or with the organization. According to one expert, "engineers would be licensed by the state, accountants certified by the CPA examination, and lawyers regulated by the bar examination, but management consultants actively campaigned to avoid government oversight" [McKenna 2000]. Our research has shown also that solo or small firm management consultants like the certification, but larger consultancies discourage their staff, insisting that professionalism resides with the organization [Gross and Poor 2008; O'Mahoney 2010].

Table 3. Standards Set by Two Key Groups for Qualifying as

a Certified Management Consultant (Cmc)

\begin{tabular}{|c|c|c|}
\hline Procedure & ICMCL. org & IMCUSA. org \\
\hline Requirements & Three years in & Three years in \\
\hline Experience & $\begin{array}{l}\text { management } \\
\text { consulting }\end{array}$ & $\begin{array}{l}\text { practice as full-time } \\
\text { consultant, with } \\
\text { much responsibility }\end{array}$ \\
\hline Education & $\begin{array}{l}\text { Recognized degree or } \\
\text { additional live years } \\
\text { in mgmt. } \\
\text { cons, in lieu of } \\
\text { degree }\end{array}$ & $\begin{array}{l}\text { Degree from a } \\
\text { four-year college }\end{array}$ \\
\hline Time spent & $\begin{array}{l}1200 \text { hours/annum in } \\
\text { active mgmt. cons, } \\
\text { during } 3 \text { of? } \\
\text { yrs or currently } \\
\text { active in mgmt. } \\
\text { cons. }\end{array}$ & (no such heading) \\
\hline Engagements & (no such heading) & $\begin{array}{l}\text { Written summaries and } \\
\text { discussion of panel } \\
\text { of five } \\
\text { client assignments }\end{array}$ \\
\hline
\end{tabular}




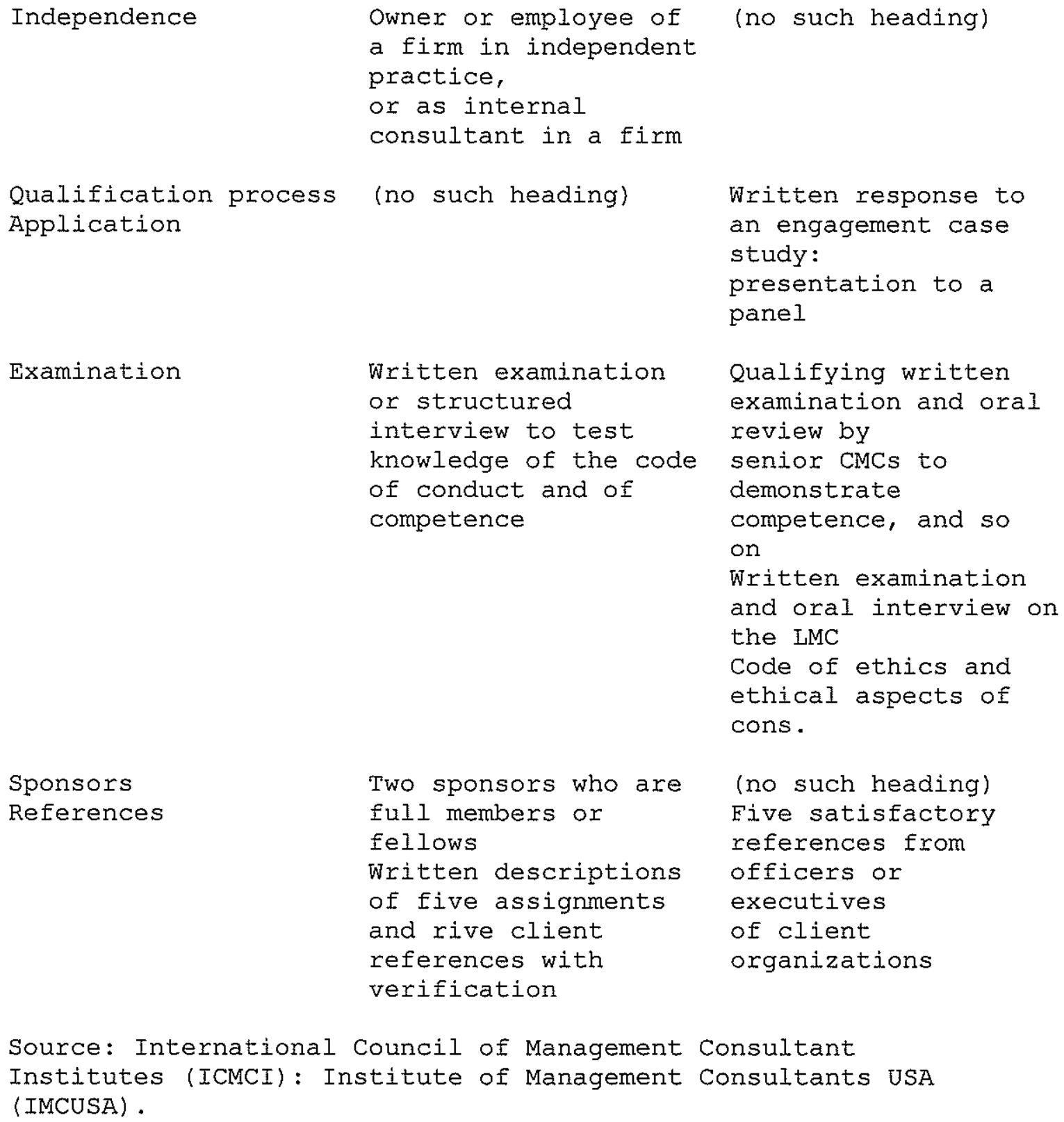

Source: International Council of Management Consultant Institutes (ICMCI): Institute of Management Consultants USA (IMCUSA).

\section{Professional Service Firms}

Scholars in history, sociology, economics, and education have focused on professionals by emphasizing their career patterns, compensation, and the utilization of education at work. In contrast, academics and practitioners from management, organizational behavior, and marketing areas prefer to look at professional service firms and analyze issues at that level. They often see such firms as entrepreneurial ventures, with cutting edge activities, even as some become medium to large employers. Emphasis in this context is given to innovation, governance, ownership, talent recruitment, client relationship, market share, and strategy for multinational entry and expansion. Overall, an encouraging picture emerges: professional service firms are experiencing growth in many nations, including the EU, North America, Japan, and Australia with opportunities to extend across borders.

Among the positive forces influencing the operations and future welfare of professional service organizations is the demand by clients for solid advice with harmonized, uniform standards in meeting government regulations, as in accounting, law, and engineering. There is a growing talent pool from universities in all regions: graduates enjoy mobility. Certification and licensure are seen as an assurance for maintaining quality. On the other hand, professionals and professional service firms are threatened by "paraprofessionals" in each field as well as technology offering software assistance and automated reports from online providers. Western firms see 
competition from low-wage countries even as they do outsourcing; they also object to visa restrictions on immigrant engineers. Last, but not least, clients are objecting to higher fees by accountants and lawyers and to "add-on" charges by engineering consultants. The widespread custom of "billable hours" by many large law firms is under attack, and specific reforms have been proposed [Henderson 2013, Spector 2013, Susskind 2013]. There is increased pressure for higher productivity, accountability, and transparency; clients now demand not just advice but implementation [Steiger 2008].

The majority of studies on professional services focus either on one sector [Curnow and Reuvid 2003, Osegowitsch 2003, Susskind 2013] or on a broad landscape without mentioning any specific professional sector [Maister 1993, Maister 1997, Teece 2003]. However, there are several comparative studies [Malhotra and Morris 2009, Von Nordenflycht 2010], and some cut boldly across several fields [Aquila and Marcus 2004]. We discuss four major sectors below: accountancy, legal services, engineering consultancy, and management consultancy. But before doing so, we wish to illustrate the viability and persistence of small firms and entrepreneurship in the West.

\section{Small Firms and Entrepreneurship in the West}

In his historical, in-depth treatise of the small business sector of the United Kingdom and other Western nations, Storey struggled with definitions and statistics [Storey 1994]. What is a small firm? When is a small firm created? When does it cease to exist? He devoted three separate chapters to these topics and reviewed many earlier studies. The importance of the small business sector in the vitality of both industrialized and emerging economies was not an issue, but actual measurement was problematic. In his view, "the economic and statistical definitions employed by the Bolton Committee of 1971 (a United Kingdom government group) are no longer relevant." However, "whilst broadly acceptable and consistent definitions are needed for international and time series comparisons, small firm researchers are not restricted by these parameters" [Storey 1994].

The research done in the past two decades shows clearly that new small firm formations and entrepreneurial ventures play a major role in the overall economies of all nations [Dana 2004; Gartner and others 2004; Cassis and Minoglou 2005; Kressel and Lento 2012]. As expected, rates vary markedly from one sector to another, from one time period to another, and from one country to another; however, profitability and cash flow are two key requirements. Since 1999, the Global Entrepreneurship Monitor (GEM) project has conducted surveys in many countries. The 2012 report encompassed entrepreneurial activity in 69 nations, representing 87 percent of global GDP and 74 percent of the world population [Xavier and others 2012].

Looking at the industrialized Western nations, which they call innovative-driven economies, the authors of the 2012 report found that only 5 to 15 percent of the 18-64-year-old group got involved in "total early-stage entrepreneurial activity or TEA." In emerging, factor-driven economies the range was 1242 percent, while in the mid-range, efficiency-driven economies it was 5-25 percent [Xavier and others 2012]. The highest TEA rates were found in sub-Saharan Africa and Latin America/Caribbean. The GEM reports put much emphasis on positive attitudes, intentions, beliefs, and then focus on nascent and new entrepreneurs. Another key research topic is whether new firms are "pushed into" entrepreneurship by lack of alternative employment or are "pulled in" by market opportunities; the former is more applicable to the emerging, the latter to the mature economies. Finally, the GEM reports show that education, innovation, and government policies can make a difference.

The creators of GEM have established an interactive website, gemconsortium.org, where it is possible to find a wide variety of indicators and over 30 nations for comparison. Together, they offer an opportunity for meaningful contrast and comparison. There are nine indicators for entrepreneurial activity, three for entrepreneurial aspirations, and eight for entrepreneurial attitudes. We have chosen two from the first, one from the second, and one from the third category to illustrate changes in three British Commonwealth nations. In Table 4 we show the respective data for Australia. Canada, and the United Kingdom during 2002-2010. Not surprisingly, the two former colonies, younger nations by far, show a higher rate on the four indicators than the United Kingdom. But all three countries display stability and (not shown here) measure up well vis-a-vis many other EU nations.

Table 4. Select Entrepreneurial Indicators for

Three Majox British Commonwealth Nations 


\begin{tabular}{|c|c|c|c|c|c|c|}
\hline Country & Indicator & 2002 & 2004 & 2006 & 2010 & 2011 \\
\hline \multirow[t]{4}{*}{ Australia } & $\begin{array}{l}\text { Established } \\
\text { business } \\
\text { ownership (1) }\end{array}$ & 7.7 & 9.6 & 10.4 & 8.5 & 8.1 \\
\hline & $\begin{array}{l}\text { Total } \\
\text { entrepreneurial } \\
\text { activity (2) }\end{array}$ & 8.7 & 13.4 & 11.9 & 7.8 & 10.5 \\
\hline & $\begin{array}{l}\text { New product early } \\
\text { stage activity } \\
\text { (3) }\end{array}$ & 37 & 39 & 36 & 36 & 41 \\
\hline & $\begin{array}{l}\text { Entrepreneurial } \\
\text { intention (4) }\end{array}$ & 7.8 & 15.5 & 10.6 & 8.7 & 12.3 \\
\hline \multirow[t]{4}{*}{ Canada } & $\begin{array}{l}\text { Established } \\
\text { business } \\
\text { ownership (1) }\end{array}$ & 6.5 & 7.0 & 5.1 & $\mathrm{NA}$ & $\mathrm{NA}$ \\
\hline & $\begin{array}{l}\text { Total } \\
\text { entrepreneurial } \\
\text { activity (2) }\end{array}$ & 8.5 & 8.8 & 7.1 & $\mathrm{NA}$ & NA \\
\hline & $\begin{array}{l}\text { New product early } \\
\text { stage activity } \\
\text { (3) }\end{array}$ & 51 & 47 & 44 & $\mathrm{NA}$ & $\mathrm{NA}$ \\
\hline & $\begin{array}{l}\text { Entrepreneurial } \\
\text { intention }\end{array}$ & 6.9 & 8.1 & 8.3 & $\mathrm{NA}$ & $\mathrm{NA}$ \\
\hline \multirow[t]{4}{*}{$\begin{array}{l}\text { United } \\
\text { Kingdom }\end{array}$} & $\begin{array}{l}\text { Established } \\
\text { business } \\
\text { ownership (1) }\end{array}$ & 5.5 & 5.1 & 5.4 & 6.4 & 7.2 \\
\hline & $\begin{array}{l}\text { Total } \\
\text { entrepreneurial } \\
\text { activity (2) }\end{array}$ & 5.4 & 6.2 & 5.8 & 6.4 & 7.3 \\
\hline & $\begin{array}{l}\text { New product early } \\
\text { stage activity } \\
\text { (3) }\end{array}$ & 36 & 42 & 38 & 30 & 52 \\
\hline & $\begin{array}{l}\text { Entrepreneurial } \\
\text { intention (4) }\end{array}$ & 4.2 & 7.4 & 5.6 & 5.1 & 5.8 \\
\hline
\end{tabular}

Source: http://www.gemconsortium.org/data.

Notes: (1) Percent of population ages 18-64 who own and run an established business.

(2) Perccnt of population ages 18-64 who own and run new business (TEA). 
(3) Percent of TEA whose product-service

is new to some customers.

(4) Percent of population ages 1-64

who intend to start a business within three years.

Combining academic and practitioner evidence [Bowen and DeClerq 2008; Anokhin and Wincent 2012; Xavier and Others 2012; Kressel and Lento 20121, the key to survival for young firms appears to lie in growing fast after startup, adjusting the product-market interface, and achieving a diversified customer base. Where there is a "winner-take-all" market, entrepreneurs need substantial financial assistance and deep insights into technology. Capability should be tailored to client needs, and products or services should not be "over-engineered." Enthusiasm, motivation, and team effort by a dedicated cadre of individuals loom important as do resources and characteristics of both the firm and the sector(s) in which it is operating. Others suggested looking for insights by examining the different stages of small business growth. Many analysts propose marrying marketing orientation (emphasis on client/customer focus, profitability and coordination) and entrepreneurial orientation (innovation, pro-activeness and risk acceptance). Hypotheses abound, studies are conducted; and more precise conclusions should emerge. There are encouraging statistics already shown below to illustrate optimism for both the United States and the EU.

\section{Enterprise Demographics in United States and European Union}

The U.S. Small Business Administration and the U.S. Census Bureau have been collecting data on the births and deaths of U.S. firms as well as on the expansions and contractions of existing firms. These time series are now available from 1990 to 2007, but not for the most recent period. Examination on a year-to-year basis reveals highly stable patterns that are encouraging. For births during 1990-2007 the range was from 540,000 to 670,000 firms and for deaths it was 512,000 to 599,000 [U.S. Census Bureau 2011]. In both series, firms with less than 20 employees accounted for over 90 percent of the total. The latest data from the United States, for the recession year of 2009, seen in Table 5, offer some encouraging signs, especially for start-up firms. More recently, however, there are dark clouds on the horizon with three of four ventures failing [Gage 2012]. We think a steady recovery pace in the United States in this decade will encourage more entrepreneurial activity.

Table 5. Establishment Births, Deaths, and Employment by Firm Type in High-Level Service Sector, United States, 2009 (in thousands)

Part A

Sector and Establishments

firm type (in 000s)

Services*: Number Births Deaths

Startups

(1)

Young firms

(2)

Mature firms

(3)
(4)

184

184

\author{
Number of \\ employees (in \\ 000s)
}




\begin{tabular}{|c|c|c|c|c|c|}
\hline & $\begin{array}{l}\text { Employment } \\
\text { (in 000s) }\end{array}$ & & & & \\
\hline Services*: & Net total & $\begin{array}{r}\text { Due to } \\
\text { births } \\
\text { (4) }\end{array}$ & $\begin{array}{r}\text { Due to } \\
\text { deaths } \\
\text { (5) }\end{array}$ & $\begin{array}{r}\text { Due to } \\
\text { birth and } \\
\text { expansion } \\
(6)\end{array}$ & $\begin{array}{r}\text { Due to death } \\
\text { and } \\
\text { contraction } \\
(6)\end{array}$ \\
\hline $\begin{array}{l}\text { Startups } \\
\text { (1) }\end{array}$ & 931 & 931 & -- & 931 & - \\
\hline $\begin{array}{l}\text { Young firms } \\
\text { (2) }\end{array}$ & -768 & 200 & 1,015 & 1,830 & 2,598 \\
\hline $\begin{array}{l}\text { Mature } \\
\text { firms (3) }\end{array}$ & $-1,021$ & 665 & 1,015 & 3,567 & 4,588 \\
\hline
\end{tabular}

Source: This is part of Table 764 in The Statistical Abstract of the United States, 2012.

Notes: * These services exclude: finance, insurance, real estate: retail and wholesale; transportation. communication. and utilities: thus. while not specified. this list most likely. includes the following: professional technical and administrative-managerial services. See listing in source cited for detail.

(1) Less than 1 year old.

(2) 1-10 years old.

(3) More than 10 years old.

(4) Birih year is defined as the year an establishment first reports positive employment.

(5) Death year is defined as the year an esuiblishment nently shuts down.

(6) For explanation of expansions and contractions, see the following wcbsite. http:www.ces.census.gov/indcx.php/bds/bds_overview.

In the EU, its statistical arm, Eurostat, collected data from member nations and arranged them in many databases (especially a comprehensive one, called SBS/Structural Business Statistics]; it has published both short and long reports on technical, economic, and business topics [Eurostat 2011;2013]. In 2011, around 76 million persons were employed in knowledge-intensive activities in the 27 countries of the EU as of June 2013, with Belgium, Ireland, Luxembourg, Malta, Sweden, and United Kingdom ranking at the top. Small- and medium-sized enterprises or SMEs were important players in the national and local economies of the region. In Table 6, we see an enterprise size class analysis of key indicators in the EU-27 nonfinancial business economy as of 2008. More than nine out of 10 enterprises are micro; however, their roles in workforce and value added are considerably lower. The distributive trades rank first in SMEs, with 6.1 million. Professional, scientific, and technical activities SMEs are in second place at 3.3 million. A historical and economic overview of four categories, followed by data for three EU nations, is discussed below. 
Table 6. Enterprise Size Class Analysis for

Nonfinancial Business Economy, European Union--27 Nations, 2008

Part A

$\begin{array}{rrrr}\text { Number of } & \text { Persons } & \text { Value } & \text { Apparent Labor } \\ \text { Enterprises } & \text { Employed } & \text { Added } & \text { Productivity } \\ \text { (million) } & \text { (million) } & \text { (billion } & (1,000 \\ & & \text { euro) } & \text { Euro/Person) }\end{array}$

\begin{tabular}{|c|c|c|c|c|}
\hline $\begin{array}{l}\text { All } \\
\text { enterprises }\end{array}$ & 21.0 & 135.8 & 6176 & 45.5 \\
\hline All SMES & 20.9 & 90.6 & 3617 & 39.9 \\
\hline Micro & 19.3 & 39.3 & 1348 & 34.3 \\
\hline Small & 1.4 & 27.9 & 1147 & 41.2 \\
\hline Medium & 0.2 & 23.4 & 1122 & 47.9 \\
\hline \multirow[t]{3}{*}{ Large } & 0.0 & 45.2 & 2559 & 56.6 \\
\hline & Part B & & & \\
\hline & $\begin{array}{r}\text { Number of } \\
\text { Enterprises } \\
\left(\begin{array}{l}8 \\
8\end{array}\right. \\
\text { Total) }\end{array}$ & $\begin{array}{l}\text { Persons } \\
\text { Employed (8 } \\
\text { of Total) }\end{array}$ & $\begin{array}{l}\text { Value } \\
\text { added ( } \\
\text { of Total) }\end{array}$ & $\begin{array}{r}\text { Apparent Labor } \\
\text { Productivity } \\
\text { (\% Rel. to } \\
\text { Total) }\end{array}$ \\
\hline $\begin{array}{l}\text { All } \\
\text { enterprises }\end{array}$ & 100.0 & 100.0 & 100.0 & 100.0 \\
\hline All SMEs & 99.8 & 66.7 & 58.6 & 87.8 \\
\hline Micro & 92.0 & 29.0 & 21.8 & 75.3 \\
\hline Small & 6.7 & 20.5 & 18.6 & 90.5 \\
\hline Medium & 1.1 & 17.2 & 18.2 & 105.3 \\
\hline Large & 0.2 & 33.3 & 41.4 & 124.5 \\
\hline
\end{tabular}

Source: Eurostat [2011].

Note: Eurostat defines micro enterprises as those with less than 10, small with 10-49, medium with 50-249 persons employed. Statistics on births, deaths, and survival of SMEs by countries and industry sectors are not readily available now.

5. Accounting/Accountancy

History and structure

Accounting looks back on centuries of history with the earliest records of business transactions dating back to 7000 B.C. Two key branches are managerial accounting for internal decisions about operations and financial 
accounting for external audiences. Practitioners need certification, and continuing education is often mandated. Large multinational companies and governments continue to push for more uniformity and reconciling U.S. with EU standards. The global accounting sector is dominated by the Big Four (formerly Big Eight, then Big Six): Deloitte, Ernst and Young, Pricewaterhouse-Coopers, and KPMG, which have over half of the global market. On average, each of the Big Four had annual revenue of around $\$ 26$-billion, over 115,000 staff members in 140 countries and 800 office locations, and earned about $\$ 110$ billion in 2012. In comparison to the Big Four's $\$ 110$ billion, the next 35 firms had combined revenue of only $\$ 60$ billion. Yet there is room for mid-tier firms. For example, Grant Thornton acquired nine firms in emerging markets. The trend for mid-size firms is to expand regional coverage via networks, associations, and alliances. The SMEs often function in a single major country and tend to specialize, but with unique skills they can cross borders.

\section{Services and clients}

Accountancy firms offer a wide variety of services. For the Big Four, audits were responsible for 45 percent, tax services for 23 percent, and advisory services for 22 percent of total revenues in 2012 . By offering forensics, litigation, governance, technology, and risk management, they challenge law firms and consultancies. Success comes from providing "one-stop-shopping," global perspective, economies of scale, and building trust [Smith 2012; International Accounting Bulletin 2013]. Clients seek assistance on compliance, transfer pricing, and taxation [Gyorkos and Maher 2012; Shtatnov 2012: International Accounting Bulletin 2013]. In terms of regions, North America and Europe bring in much of the revenue; but China, India, sub-Sahara Africa, and Singapore represent growing markets for firms $1 \mathrm{~mm}$ the West. However, the Chinese Ministry of Finance is said to be intent on developing 10 large and 200 medium-size accountancy firms, and Singapore plans to be a leading hub for both auditing and a center for continuing professional development and training for accountants.

\section{Law/Legal Services}

History and structure

In ancient Greece, Aristotle embraced the idea that "the rule of law is better than the rule of any individual." In the modem era, this paradigm comes through the courts, judgments, and licensing of lawyers (also known as attorneys, barristers, solicitors, advocates, and counselors). Three legal systems are in place globally: common law, based on precedents; civil law, based on administrative codes; and theocratic law, based on religious teachings. Required education for the legal profession varies nation by nation. Some countries insist on a prior degree, while others emphasize on-the-job training. Some observers see danger in outsourcing and automation; others call for reforms in "the billable hours" practice; and some want to modify ownership, allowing a role for nonlawyers [Faulconbridge and others 2007-2008, Henderson 2013, Susskind 20131. The legal sector is fragmented, with revenues of the top five--Baker and McKenzie, DLA Piper, Skadden Arps, and Latham and Watkins of the United States, and Clifford Chance of the United Kingdom--in the range of $\$ 2.0-\$ 2.3$ billion, which is modest in contrast to the $\$ 22-\$ 29$ billion range for the Big Four accountancy firms. Additional evidence for the fragmentation in legal services is the presence of Australian, Chinese, and Spanish law firms in the top 100 list.

\section{Services and clients}

Traditional legal fields are criminal, contract, family, property, patent, tax, and tort law. New areas are international, intellectual property, environmental, and space law. Small firms often tend to specialize in one of these areas; a popular one in the United States is the field of personal injury. Large firms offer a wide range of services, around the world, with both litigation and transactional assistance. The former involves representing the clientele in courts, the latter deals with preparation of documents and ensuring compliance. Mediation and arbitration pose alternatives to lawsuits, but disruptive technologies also threaten the transactional practice of law. Large law firms tend to cater to large clients, mid-tier firms to mid-size clients, and small firms to small-size clients; this implied "comfort zone" of participants also links compensation to the quality of work, that is if it is "pricey" it must be high quality and vice-versa. Clients now benefit from increased collaboration between inhouse legal departments (known as general counsels in the United Kingdom) and outside law firms. Both transaction management and litigation are ripe for decomposition through wider use of junior associates, paralegal staff, and online resources. This will lead to lower charges to clients who have been asking for just that. 


\section{Engineering Consultancy}

History and structure

This sector is technology-laden with a long history and with deep ties to both construction and manufacturing. Military and civil engineering trace their roots back centuries to the building of fortifications and bridges. Other engineering specialties developed much later as scientific discoveries: these range from aeronautical to biomedical engineering. Though the profession is ancient, formal education is relatively new, but rigorous: and there is debate about the content of the curriculum. China and India offer growing talent pools for engineering consultants, though quality of their graduates can vary greatly. Global revenue has been estimated at over $\$ 550$ billion, with three million "associates" in 500 thousand firms [Gross 2012]. There is fragmentation in this sector, just as in legal services. The top 10 firms have only 12 percent of global market share. The largest firms have headquarters in the United States, EU, Australia, and Canada. Small firms with less than 10 associates still account for 65-75 percent of total revenue in many nations. All players must adjust to the location of project offices--unlike in accounting, legal services, and management consultancy--wherever the client requires new facilities or renovating old ones. Large firms in this sector "follow the client, follow the money," while small ones often act as subcontractors.

\section{Services and clients}

Engineering faculties offer-civil, electrical, mechanical, and other fields of study, and this is reflected in practice as well. However, the consultancies--whether inhouse or independent--often specialize along major end-use markets such as energy, transportation, pollution control, and manufacturing. Large-scale projects are lucrative, so large engineering firms, such as Arcadis, Bechtel, Fluor, Fugro, KBR, and URS cultivate "contacts in high places" [McCartney 1988]; but bribes can no longer be offered under the Organisation for Economic Cooperation and Development Convention (OECD) of 1999, though "facilitating payments" are still permissible. The keys to success lie in building new contacts, cultivating existing relationships, and being flexible while moving across, projects and national boundaries. The major customers are governments, manufacturers, and public-private partnerships. Clients need to work closely with their vendors since large projects require astute cost estimation and cultivation of relationships. The trend by vendors is to bid low, then charge "add-on" fees. But an encouraging sign is the dedication to implementation and sustainability by both vendors and clients. Completing projects on time and budget are seen as vital, as are "eco-friendly or green" practices. Metrics are now standard for achieving goals, energy and water use, emission control, and recycling rates.

Additional information on this sector can be found in Gross [2012]

\section{Management Consultancy}

History and structure

Although other professional services trace their roots back centuries, this sector is less than 150 years old. "Advisory practices" began in the 1860s in the United Kingdom; the first "pure consultancy" in the United States is attributed to Arthur D. Little, with a focus on technology and engineering economics. This was followed by the start-ups of Edwin Booz, James McKinsey, and Andrew Kearney whose names survive in company names. McKenna [2006] argues that flowering of management consultancies during 1925-1940 was not due to scientific management, but to emulating three professions (accounting, law, and engineering), the role of merchant bankers, and favorable legislation. David [2001] found several forces explaining the rise of this sector: increasing complexity of operations, spread of corporate ideology, growing impact of business education, and the business press. He argues that only large firms can afford to be generalists, small ones should be specialists. Global revenue is put over $\$ 300$ billion, with North America still accounting for about half and the EU for one-third of the world market. Among the "classic" firms are Bain, BCG, Booz, McKinsey, A.T. Kearney, and A.D. Little. The Big Four of accounting either stayed in management consulting or returned with a definite impact. Moreover, Accenture and IBM, both with emphasis on information technology, now have the largest market share at roughly 8 and 15 percent. The large Indian films of Infosys, Tata Consulting, and Wipro are now coming on strong by offering technical talent at lower cost and guarantees. 
Services and clients

For several decades management consultants have divided their offerings as: strategy; human resources; operations; and information technology. To these four categories, outsourcing has been added. To succeed in all these tasks, teams of generalists and specialists are assembled, plus country or local experts. Management consultants have moved into accounting. Financial, legal, and technical counseling, just as firms in those areas penetrate this field. Success is built on referrals, repeat business, and reputation. Accordingly, consultants publish articles, seek testimonials to build reputation, and strive to build their firms' name into "brand equity." Who buys all that advisory or consulting service? The major end users are the "usual suspects": the private sector, governments, and nonprofit organizations. But further breakdown is available from corporate annual reports, press releases, "freedom of information" files, and calls for tender, as well as from research bureaus and publishers. The three leading clientele groups are manufacturing and natural resources combined, the financial sector, and then government agencies. These three account for two-thirds of the total, with the remaining onethird from service industries. Asian markets are growing far faster than those in the West, and Africa and Latin America are showing much potential. The "classic" firms are now in 20-50 countries: Accenture, CSC, Deloitte, and IBM are in over 100 nations. For an SME to expand across borders remains a challenge and is best done via specialization, service industries. Asian markets are growing far faster than those in the West, and Africa and Latin America are showing much potential. The "classic" firms are now in 20-50 countries; Accenture, CSC, Deloitte, and IBM are in over 100 nations. For an SME to expand across borders remains a challenge and is best done via specialization.

\section{The Four Professional Sectors Across Three European Union Nations}

In our task of data mining, we have been fortunate to come across three Western nations, the United Kingdom, France, and Spain that provide recent statistics on the four sectors we discussed above in a global context. In Tables 7-9, we offer data from the national statistical bureaus, supplemented by our own computation of growth rates plus two ratios: the number of staff (persons, employees) per enterprise and revenue per staff member. Please note that the time horizon is different for the United Kingdom than for France and Spain. Further, the terms or codes in each table are those used by the respective agencies and are not fully explained. However, we can still draw meaningful comparisons. We do so first for the four sectors in a given nation and then move on to contrasting the two computed ratios and growth rates across the three countries.

Table 7. Professional Services, United Kingdom, 2008--2010

200820092010 Percent Annual

Growth

Accounting and auditing

$\begin{array}{lrrrr}\text { Number employed (000s) } & 245.0 & 255.0 & 253.0 & 1.6 \% \\ \begin{array}{l}\text { Number of enterprises } \\ \text { (000s) }\end{array} & 32.8 & 32.7 & 32.8 & 0.0 \\ \begin{array}{l}\text { Total turnover (billion } \\ \text { pounds) }\end{array} & 17.8 & 19.0 & 19.4 & 2.9 \\ \begin{array}{l}\text { Employee/enterprise } \\ \text { Turnover/employee looos }\end{array} & 72.5 & 7.8 & 7.7 & 1.3 \\ \end{array}$

pounds)

Legal activities

Number employed (000s) $\quad 323.0 \quad 345.0 \quad 338.0 \quad 2.3 \%$ 


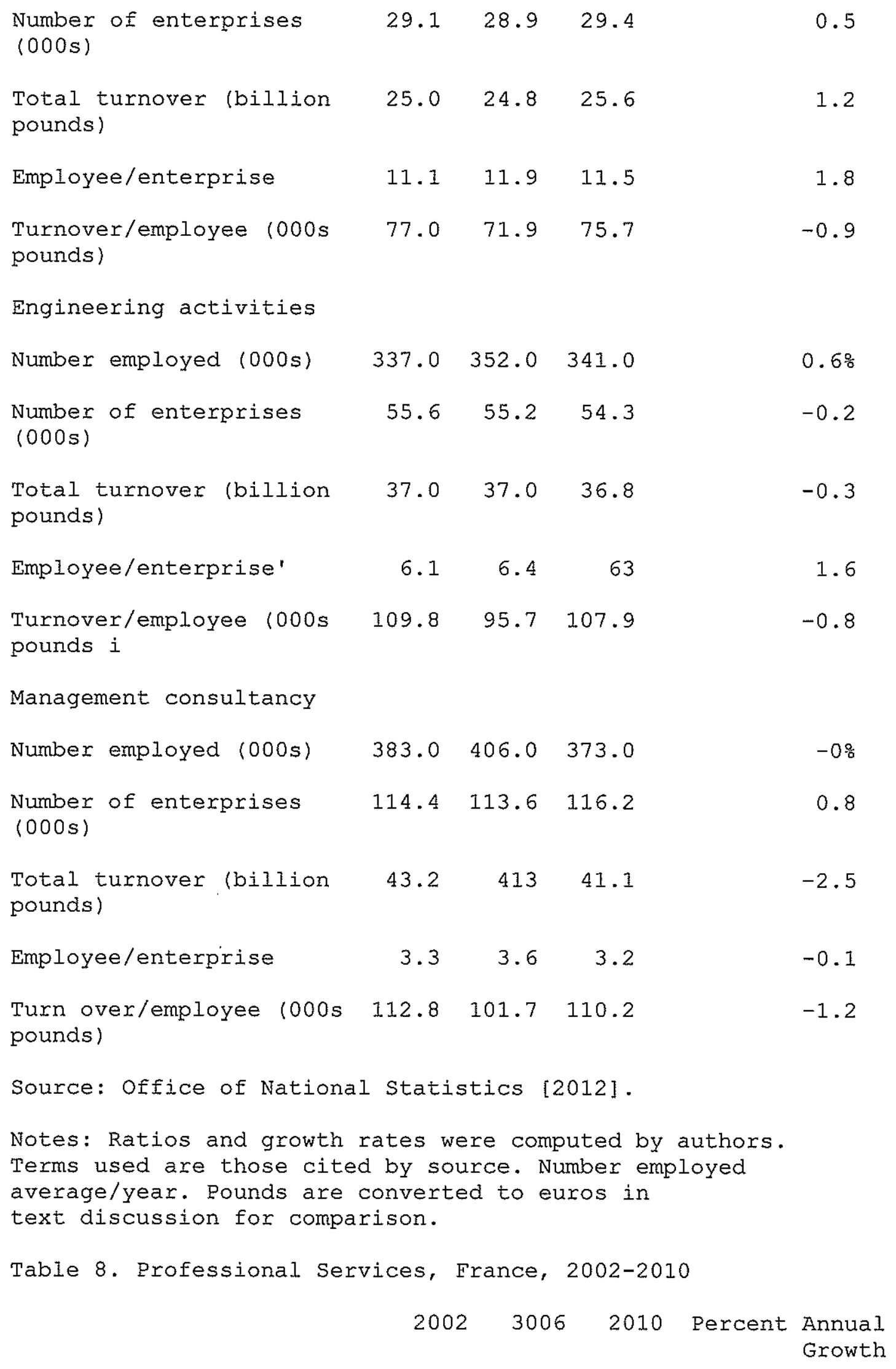

Accounting 


\begin{tabular}{|c|c|c|c|c|}
\hline Number of worker $(000 \mathrm{~s})$ & 118.2 & 124.8 & 144.4 & $2.6 \%$ \\
\hline $\begin{array}{l}\text { Number of enterprises } \\
(000 \mathrm{~s})\end{array}$ & 19.6 & 22.1 & 25.1 & 3.2 \\
\hline $\begin{array}{l}\text { Total revenue (billion } \\
\text { euros) }\end{array}$ & 28.0 & 27.5 & $\begin{array}{c}35.0 \\
\text { (e) }\end{array}$ & 2,9 \\
\hline Worker/enterprise & 6.0 & 5.6 & 5.8 & -0.4 \\
\hline $\begin{array}{l}\text { Revenue/worker lo00s } \\
\text { euros) }\end{array}$ & 236.8 & 220.3 & $\begin{array}{r}243.3 \\
(\mathrm{e})\end{array}$ & 0.3 \\
\hline \multicolumn{5}{|l|}{$\operatorname{tarn}$} \\
\hline Number of workers $(000 \mathrm{~s})$ & 106.6 & 101.4 & 100.5 & -0.7 웅 \\
\hline $\begin{array}{l}\text { Number of enterprises } \\
l(\mathrm{HH}) \mathrm{s})\end{array}$ & 43.8 & 48.0 & 52.6 & 2,4 \\
\hline $\begin{array}{l}\text { Total revenue (billion } \\
\text { euros) }\end{array}$ & 10.7 & $\begin{array}{l}7.8 \\
\text { (e) }\end{array}$ & $\begin{array}{r}19.7 \\
(\mathrm{e})\end{array}$ & 7.0 (e) \\
\hline Worker/enterprise & 2.4 & 2.1 & 1.9 & -2.6 \\
\hline $\begin{array}{l}\text { Revenue/worker } 000 \mathrm{~s} \\
\text { euros) }\end{array}$ & 100.4 & $\begin{array}{r}76.9 \\
\text { (e) }\end{array}$ & $\begin{array}{r}196.0 \\
\text { (e) }\end{array}$ & $8.8(e)$ \\
\hline \multicolumn{5}{|l|}{ Engineering consulting } \\
\hline Number el workers (000s) & 172.5 & 175.6 & 221.3 & $3.2 \%$ \\
\hline $\begin{array}{l}\text { Number of enterprise } \\
(000 \mathrm{~s})\end{array}$ & 32.6 & 34.9 & 40.7 & 2.8 \\
\hline $\begin{array}{l}\text { Total revenue (billion } \\
\text { euros) }\end{array}$ & 27.9 & 36.5 & 40.8 & 4.9 \\
\hline Worker/enterprise & 5.3 & 5.0 & 5.4 & 0.2 \\
\hline $\begin{array}{l}\text { Revenue/worker l000s } \\
\text { euros) }\end{array}$ & 161.7 & 207.8 & 184.4 & 1.7 \\
\hline \multicolumn{5}{|l|}{ Management consulting } \\
\hline Number of workers (000s) & 113.7 & 99.4 & 117.4 & $0.4 \%$ \\
\hline $\begin{array}{l}\text { Number of enterprises } \\
(000 \mathrm{~s})\end{array}$ & 59.2 & 77.9 & 94.7 & 6.0 \\
\hline $\begin{array}{l}\text { Total revenue (billion } \\
\text { euros) }\end{array}$ & $6.2(e)$ & $7.5 e$ & $\begin{array}{r}8.8 * \\
\text { (e) }\end{array}$ & 4.4 \\
\hline Worker/enterprise & 1.9 & 1.3 & 1.2 & -5.8 \\
\hline
\end{tabular}




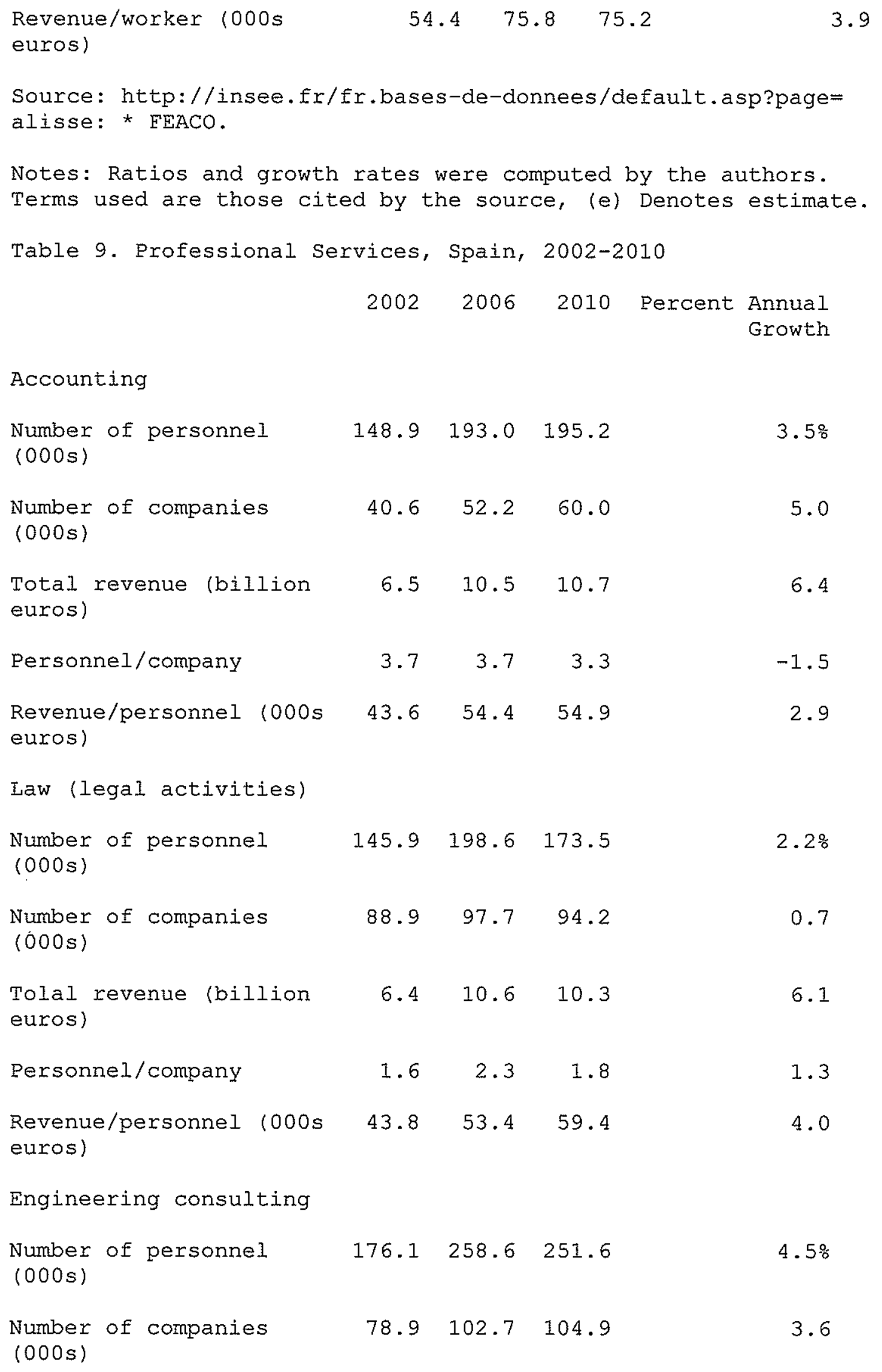




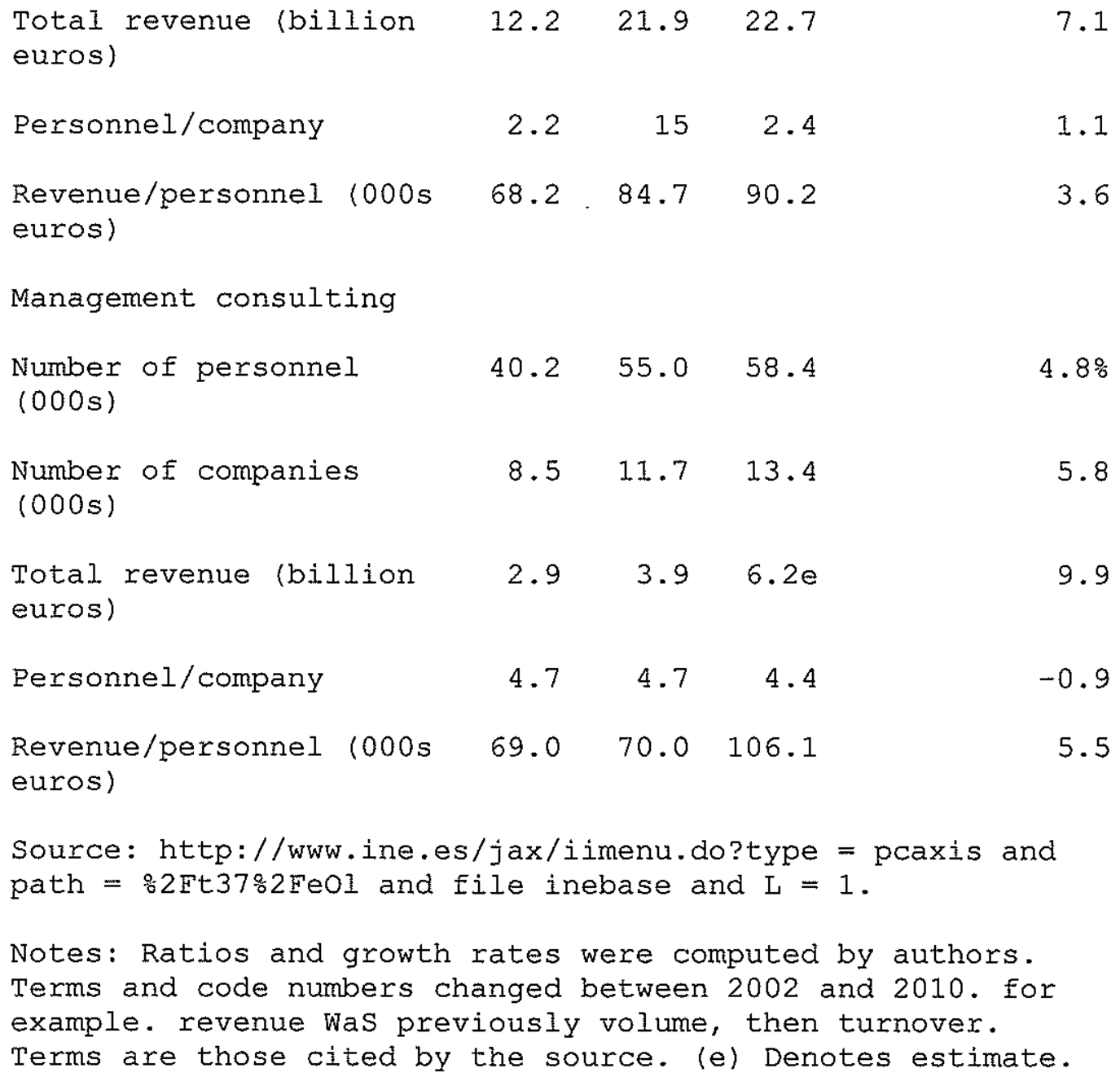

In Table 7, we note that in the United Kingdom three of the four professional service sectors employed 250.000350,000 persons working in about 30,00050,000 enterprises. Total turnover has been steady during 2008-2010. Employees per enterprise have been stable as well, with about 7-8 persons in accounting, 11-12 in legal services, and around six in engineering consultancy. In the case of management consultancy, both the staff and the firm numbers are significantly higher, as managers of large firms sometimes go into self-employment or start a small enterprise. Thus, there are only 3-4 employees per enterprise. Earnings per employee are around 75,000 pounds per year in accounting and legal activities and about 105,000 pounds in engineering and management consultancies. These remuneration patterns may reflect demand-supply facets as well as institutional context.

In Table 8, we are looking at the four sectors in France during 2002-2010, noting that some of the numbers are questionable despite our best efforts to ascertain them (as indicated by e). There are between 100,000 and 200,000 workers in each category, while the enterprise numbers range from around 22,000 in accounting to 75,000 in management consulting. Total revenues, seem very low in legal services, which may in part be due to the fact that France follows the Napoleonic code law system with heavy reliance on the work of notary publics rather than lawyers. The worker to enterprise ratio has been about six in accounting, two in law, five in engineering, and between one and two in management consultancies. The revenue per worker statistics show relatively high earnings in the first three sectors at over 100,000 euros per year, but low remuneration in management consulting, which is not at all surprising given both the tradition in labor market conditions and the recent rise in supply of management consultants in this nation. Accountants, lawyers, and engineers are valued more, and entry into these professions is much more difficult, hence supply is stable.

Table 9 presents data for Spain, a nation that has had a high unemployment rate recently (over 25 percent), especially for those under 25 (over 50 percent). In our data set, we find the number of employed personnel in the 
first three sectors in the $150,000250,000$ range, but in management consultancy only around $40,000-60,000$. The number of accounting firms rose from 40,000 to 60,000 in eight years, in the legal area it remained around 93,000 , and in engineering rose from 79,000 to 105,000 . These numbers possibly reflect the earlier boom years in real estate and construction along the Costa del Sol. The average personnel per company was steady with 3-4 in accountancy, two in law, 2-3 in engineering, and 4-5 in management consultancy. Revenue per person has shown increases, with 44,000-59,000 euros in accounting and legal services, 68,000-90,000 in engineering, and 69,000106,000 in management consulting.

Looking at Tables 7-9 across the four sectors in the three nations, in terms of ratios and growth rates, we find either stability or steady growth, with a few minor exceptions that indicate decline. Thus, in accountancy persons per company were around eight, six, and four, respectively in the three countries; for law the figures are 1-2; engineering 2-6; and management consultancy 2-5. The revenue per employee data shows higher remuneration rates in United Kingdom and France than in Spain, which is not surprising in light of economic development, tradition, and "customary" remuneration patterns. As a general rule, the older professions of accountancy, law, and engineering pay better than the newer field of management consultancy, though the United Kingdom is an exception to that rule, which is probably a consequence of the sector originating in that nation. All in all, we are encouraged by the steady state--and in some instances, steady advance in the number of persons employed, number of firms established, the two computed ratios, and the annual growth rates.

\section{The Path for Professional Enterprises in the West}

We started this essay with a brief overview on the growth of knowledge-intensive services in both mature and emerging nations, followed by discussion about professions and professional services. Then we focused on the role of small firms in the West and enterprise demographics in the United States and the EU. Four distinct sectors were highlighted next, first in a global context, then within three major Western nations: accountancy, legal services, engineering consultancy, and management consultancy. Coverage included the history and structure of the sectors, followed by service offerings and identifying the client base. As each of the four sectors is embedded in its past and current institutional context, each one is evolving in its own way. The discussion illuminates the four major sectors and three large Western countries, using both key ratios and annual growth rates.

In Table 10, we summarize the four sectors vis-a-vis external challenges, industry drivers, and the currently important issues of ethics and trust. There are clear differences as well as similarities among the four sectors. The roadmap for the future will depend on how each sector resolves its challenges. The most intriguing facet, however, is likely to be the question of competition not just within one field, but rivalry among the sectors in the future. Fundamentally, all four sectors are advising business clients about strategy and tactics in planning and managing. It is likely that they will invade each other's turf in an aggressive way in the near future--especially in the West with its mature markets.

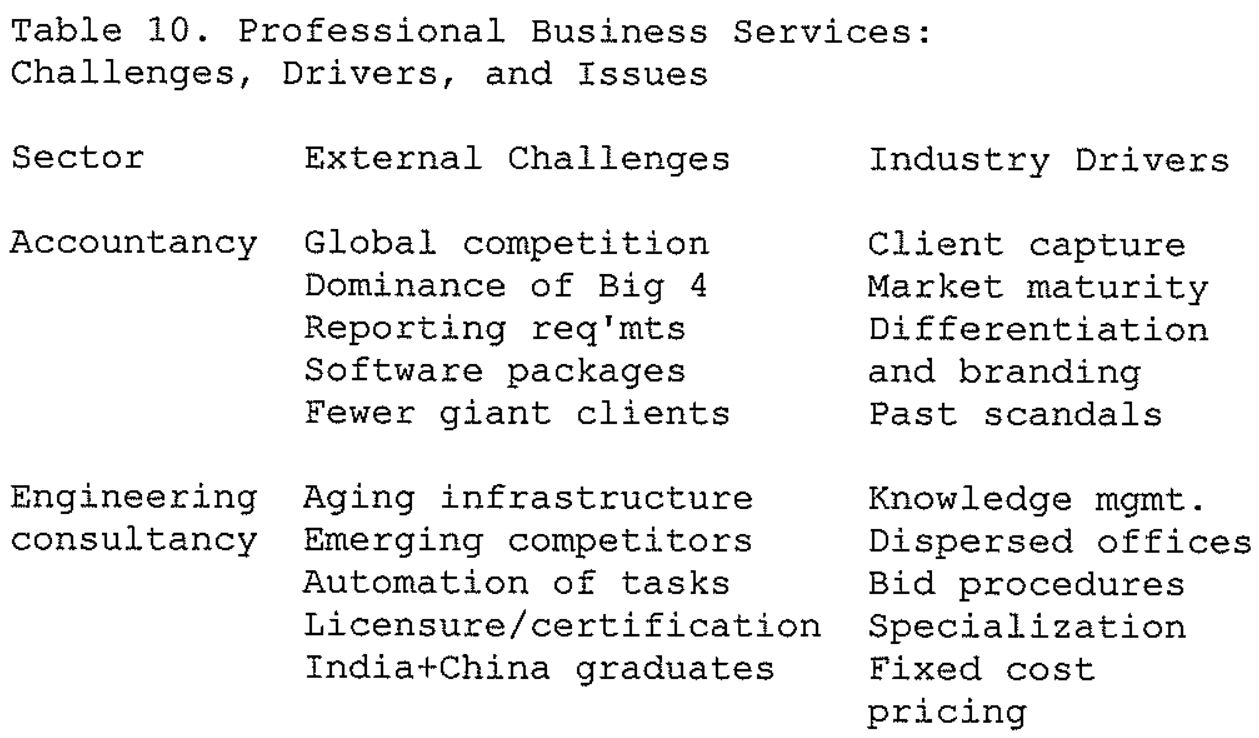




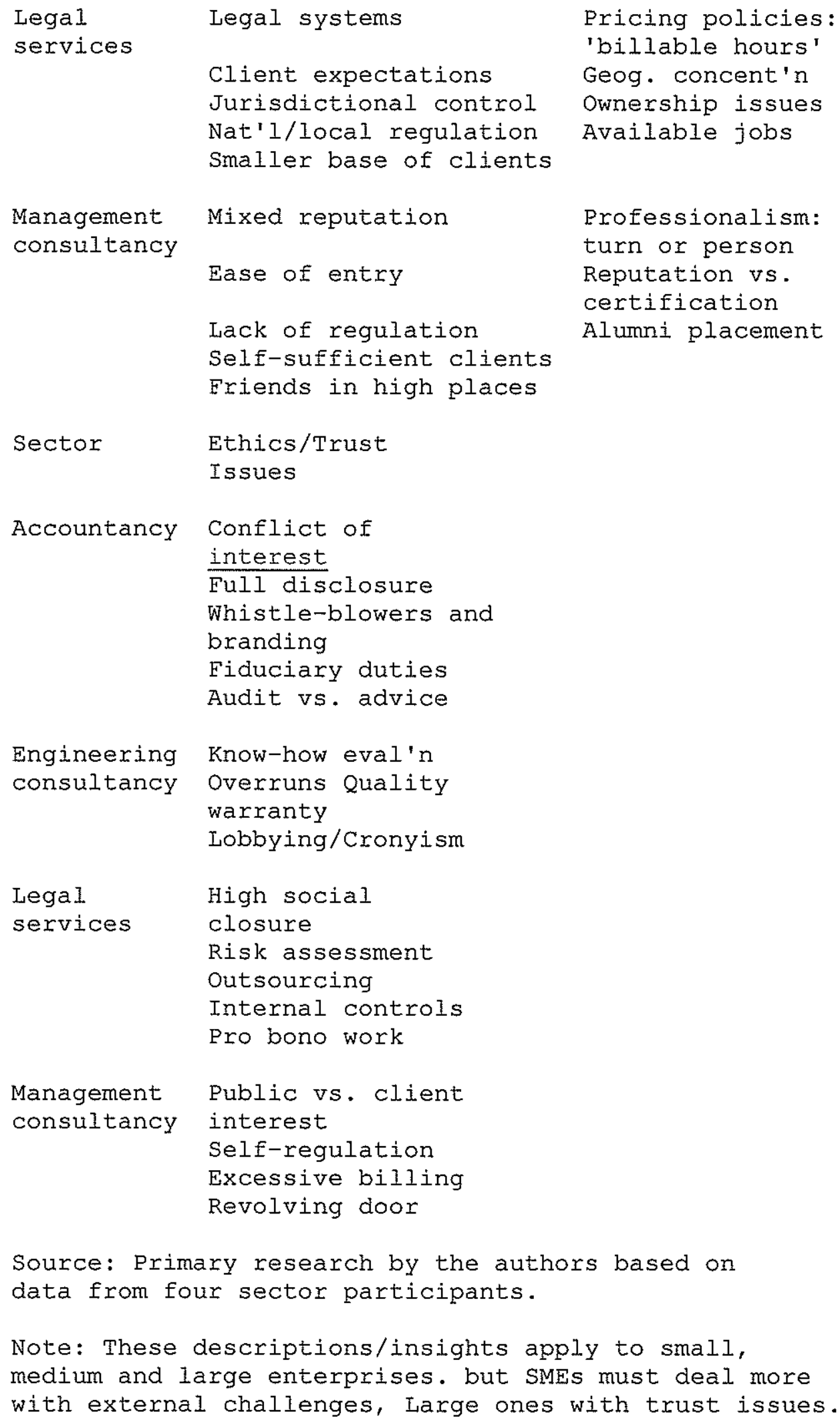

At the start of this paper we quoted from a 2004 issue of The Economist. According to the article, accounting firms were already among the more aggressive globalizers as "they took over consultancy businesses, finance companies, and law firms, setting themselves up as global chains of one-stop shops." This created major managerial problems and potential conflicts of interest due to regulatory issues and professional duties. Further, 
few clients were buyinpg, professional services centrally. In 2013, the Big Four are still dedicated to expanding their reach despite their estimated 60 percent global market share. But medium and even small size firms are establishing network associates.

The future of each sector will depend not only on the success of existing firms, but on opportunities for the rise of new ventures. Entrepreneurship looms significant for both industrialized and industrializing nations, in both mature and emerging industry sectors. Small and medium enterprises account for 99 percent of all nonfinancial firms; the challenge is to increase their share of the labor force and of value added. In this task, both private sector enterprises and government agencies will play a key role for many years to come.

Acknowledgements

This paper was financially supported by Cleveland State University and by the Institute for the Study of Business Markets at Pennsylvania State University, with research assistance by Vivien Jancenelle, Amy Kaminsky, and Maria Ozcariz Resende.

\section{REFERENCES}

Anokhin. S. and J. Wincent 2012. "Start-Up Rates and Innovation: A Cross-Country Comparison." Jounal of International Business Studies. 43(1): 41-60.

Aquila. A., and B. Marcus 2004. Client at the Core: Marketing and Managing Today's Professional Services Firms. Wiley.

Baker, R. and P. Dunn 2003. The Firm or the Future: A Guide for Accountants, Lawyers, and Other Professional Services. Wiley and Sons.

Bowen. 14. and D. DeClerq 2008. "Institutional Context and the Allocation of Entrepreneurial Effort." Journal of International Business Studies. 39(1): 1-21.

Brock. D.. M. Powell and C. 1-linings ed 1999. The Changing Professional Organization: Accounting. Healthcare. and Law. Routledge.

Carr-Saunders. A. and P. Wilson 1933. The Professions. Oxford University Press.

Cassis, Y. and I. Minoglou 2005. Entrepreneurship-Counny Studies. Palgrave Macmillan.

Curnow, B. and J. Reuvid 2003. The International Guide to Management Consulting. Kogan Page.

Dana, L. ed. 2004. The Handbook of Research on International Entrepreneurship. Edgar Publishing.

David, R. 2001. The Emergence and Evolution of an "Expert" Field. Unpublished Ph.D. Dissertation. Cornell University.

Dezalay, Y. and D. Sugarman 1995. Pr fessional Competition and Professional Potrer. Routledge.

Eurostat, 2011. Key Figures on European Business with a Special Feature on SMEs. EU Publications Office.

--. 2013. Science, Technology, and Innovation in Europe. EU Publications Office.

Fauleonbridge, J., J. Beaverstock, D. Muzio and P. Taylor 2007-2008. "Global Law Firms: Globalization and Organizational Spaces of Cross-Border Legal Work." Northwestern Journal of International Law and Business, 28(3): 455-473.

Gage, D. 2012. "Venture Capital's Secret-3 out of 4 Start-Ups Fail." Wall Street Journal, September 20 Bl. 
Gartner, W., K. Shaver, N. Carter and P. Reynolds 2004. Handbook of Entrepreneurial Dynamics: The Process of Business Creation. Sage Publishing.

Gross, A. 2012. "The Global Engineering Consultancy Market." Business Economics, 47(4): 285-296.

Gross, A. and J. Poor 2008. "The Global Management Consulting Sector." Business Economics. 43(4): 69-78.

Gyorkos, A. and N. Maher 2012. Profession in 2020: Working Together. International Accounting Bulletin. October 22. www.internationalaccountingbulletin.com/features/ profession-in-2020-working-together (accessed September 3, 2013).

Henderson, W. 2013. A Blueprint for Change. Research Paper \#230, 40 Pepperdine Law Review 461, available, at SSRN at: http://ssm.com/abstract=2202823 (accessed September 3, 2013).

International Accounting Bulletin. 2013. 1AB World Survey 2013: A Profession Adapting to a Changing World. January 31. www.internationalaccountingbulletin.com/countrysurvey/iab-world-survey (accessed September 3. 20-13).

Kressel, H. and D. Lento 2012. Entrepreneurship and the Global Eco 170 My Cambridge University Press.

McKenna, C. 2006. The World'S Newest Profession. Cambridge University Press. Based in part on unpublished Ph.D. dissertation, Johns Hopkins University, 2000.

Maister, D. 1993. Managing the Professional Service Firm. Free Press.

-.. 1997. True Professionalism. Free Press.

Malhotra, N. and T. Morris 2009. "Heterogeneity in Professional Service Firms." Journal of Management Studies, 46(6): 895-921.

McCartney, L. 1988. Friends in High Places: The Bechtel story--The Most Secret Corporation and How It Engineered the World. Simon arid Schuster.

Morgan, J. 1998. "The Natural History of Professionalisation." Journal of Property Valuation and Investment, 16 (2): 185-206.

National Science Board, 2012. Science and Engineering Indicators, 2012. National Science Foundation NSB 1201 .

0' Mahoney, J. 2010. Management Consultancy. Oxford University Press.

Office of National Statistics (United Kingdom), 2012. Annual Business Survey, Section $M=$ Professional, Scientific and Technical Activities.

Organisation for Economic Co-operation and Development, 2001. Knowledge-Based Industries. OECD-Directorate for Science, Technology, and Industry.

Osegowitsch. T. 2003. The Relationship between Global Integration and Performance in Multinational Professional Engineering Companies. Unpublished Ph.D. dissertation, University of Western Australia.

Parsons. T. 1939. "The Professions and Social Structure." Social Forces. 17(4): 457-467.

Poor, J. and A. Gross 2003. Management Consultancy in an Eastern European Context. KIK Publishing House.

Shtatnov, A. 2012. What Law Firms Can Learn from the Accounting Sector about Providing Client Services on a Global Scale. http://ssm.com/abstract=2115057 (accessed September 3, 2013). 
Smith, P. 2012. Top 35 Networks /012: The Survey. Accountancy Age (July 9).

lutp://www.aceountancyage.com/aa/analysis/1776670/top-accounting-networks-associations-2009 (accessed September 3, 2013).

Spector. B. 2013. ABA Fundamentals: Understanding Your Business Clients. ABA Publishing.

Steiger, D. 2008. The Globalized Lawyer. ABA Publishing.

Storey, D. J. 1994. Understandinq the Small Business Sector. Routledge.

Susskind, R. 2013. Tomorrow's Lawyers. Oxford University Press.

Teece, D. 2003. "Expert Talent and the Design of (Professional Service) Firms." Industrial and Corporate Change, 12(4): 895-916.

The Economist, 2004. Home Torts from Abroad: Professional-Service Firms (February 28): 14.

U.S. Census Bureau. 2011. The Statistical Abstract of the United States, 2012. Commerce Department. Census Bureau.

Von Nordenflycht, A. 2010. "What is a Professional Service Firm? Toward a Theory and Taxonomy of Knowledge Intensive Firms." Academy of Management Review, 35(1): 155-174.

Wilensky, H. L. 1964. "The Professionalization of Everyone?" American Journal of Sociology, 70: 137-158.

Xavier. S., D. Kelley, J. Kew, M. Herrington and A. Vorderwtilbecke 2012. Global Entrepreneurship Monitor 2012 Global Report. http://www.gemconsortium.org/docs/2645/gem-2012-global-report (accessed September 3, 2013).

ANDREW C. GROSS, MARK HOLTZBLATT, RAJ JAVALGI, JOZSEF POOR, and EMERIC SOLYMOSSY 